\title{
Urgensi Aplikasi Sistem Keuangan Desa Dalam Pengelolaan Administrasi Keuangan Di Kecamatan Tebing Tinggi Kabupaten Tanjung Jabung Barat
}

\author{
Irwandi, Andrizal, Suhermi \\ Fakultas Hukum, Universitas Jambi, Indonesia
}

\begin{abstract}
ABSTRAK
Tujuan penelitian ini untuk mengetahui Urgensi program sistem keuangan desa dalam pelaksanaan anggaran desa dan mengetahui serta menganalisis kendala dalam pelaksanaan aplikasi sistem keuangan desa yang dihadapi kepala desa sebagai penyelenggaran Pemerintahan di Desa Dataran Kempas Kecamatan Tebing Tinggi Kabupaten Tanung Jabung Barat. Penelitia ini bersifat deskriptif, yaitu penelitian ini memberikan gambaran tentang Urgensi tentang perencanaan, pelaksanaan, penatausahaan, pelaporan dan pertanggungjawaban keuangan Desa. dalam pengelolaan keuangan desa dan Kendala apa saja yang dihadapi pemerintah terbawah (kepala desa beserta aparatnya dan Badan Perwakilan Desa) dalam penerapan aplikasi sistem keuangan desa dengan menggunakan cara yang dilakukan untuk mendapatkan data secara yuridis sempiris, yaitu melihat bagaimana pelaksanaan program yang sudah diatur dengan perundang-undangan dapat dilaksanakan di lapangan. (Apakah sudah sesuai antara aturan dan fakta dilapangan). Data yang digunakan adalah data primer berupa hasil observasi, wawancara, dan data sekunder. Sedangkan Informan yang digunakan adalah Kepala Desa, Operator Sistem Keuangan Desa (Siskeudes), Sekretaris Desa, Bendahara Desa, Kaur Keuangan serta Kasi pada pemerintah desa. Hasil penelitian menunjukkan bahwa pelaksanaan sistem keuangan desa dalam penginputan data harus sesuai dengan yang tertera dalam sistem; sedangkan kesediaan Sumber Daya Manusia di Pemerintahan di Desa Dataran Kempas Kecamatan Tebing Tinggi Kabupaten Tanjung Jabung Barat tidak mendukung sehingga perlu dilakukan peningkatan kapasitas melalui pendampingan atau pelatihan yang mengakibatkan Penerapan Sistem Keuangan Desa (Siskeudes) di desa Dataran Kempas belum memberikan dampak positif terhadap kinerja Kepala Desa. Hal ini menimbulkan dampak terhadap kinerja kepala desa sebagai penyelenggaaran pemerintahan desa khususnya dalam pengelolaan administrasi Dana Desa (DD) dan Anggaran Dana Desa (ADD) yang dirasakan langsung oleh pemerintah desa di Desa Dataran Kempas Kecamatan Tebing Tinggi Kabupaten Tanjung Jabung Barat. . Hal ini berbanding terbalik dengan tujuan diimplentasikannya Sistem Keuangan Desa (Siskeudes) untuk membantu kerja penyelenggaran pemerintah desa secara adminitstratif.
\end{abstract}

Kata Kunci: Aplikasi sistem keuangan desa, pengelolaan, administrasi keuangan

\section{PENDAHULUAN}

\section{Latar Belakang Masalah}

Negara kesatuan dalam teori bentuk negara adalah negara yang terdiri dari 1 (satu), 1 (satu) pemerintahan, 1 (satu) bendera, 1 (satu) bahasa, 1 (satu) budaya, 1 (satu) hukum dasar dll berdasarkan pada ideologi pancasila dan UUD 1945. Dan memiliki beberapa wilayah yang berada di bawahnya secara bertingkat diantaranya beberapa provinsi, beebrapa kabupaten dan beberapa kota. Wilayah tersebut merupakan 
perpanjangan tangan pemerintah kabupaten atau kota. Pemerintah kecamatan juga terdiri dari desa, dimana desa merupakan satu penyelenggaraan urusan pemerintahan terkecil.( Pasal 18 ayat 1,UndangUndang Dasar 1945).

Pemerintah desa sebagai pemerintah yang terendah dalam tingkatan pemerintahan di Indonesia sesuai dengan perundang-undangan yang memiliki hak otonomi, yang diakui dan dihormati dalam system pemerintahan. artinya desa memiliki kewenangan dalam mengatur rumah tangga pemerintahannya sendiri. Dengan harapan menjadikan desa bisa mengatur sendiri apa yang dikehendaki oleh masyarakat desanya sehingga pemerinta desa bisa menjadikan desanya sebagai pendukung dalam meningkatkan dan pelaksana dari asas-asas yang mengatur pelaksanaan pemerintahan dalam negara.. ${ }^{1}$ Undang-Undang Pemerintahan Desa Nomor 6 Tahun 2014 tentang Desa, salah satu pasalnya mengatur tentang pembangunan desa dimana pemerintahan desa dalam melaksanakan tugas pembangunan mendapat dana sesuai dengan program pemerintah baik jangkan panjang maupun menengah. ${ }^{2}$

Sebaliknya pemerintah desa dapat mengelola anggaran di desanya berdasarkan keuangan desa yang diatur berdasarkan perundang-undangan pemerintahan desa melaui Pendapatan Asli Desa (PAD) dan pendapatan lainnya. Anggaran Pendapat Desa memiliki peran besar mengatur dan mengurus dana desa. Sebagai pertanggung jawaban dalam mengelola keuangan desa, diperlukan sebuah system dalam rangka mewujudkan dana desa anggaran desa yang tranparan, akuntabel dan partisipatif.Lembaga yang mengatur dan memeriksa tentang keuangan desa dalam hal ini Badan Pengawasan Keuangan dan Pembangunan (BPKP) bersama dengan Kementerian Dalam Negeri (Kemendagri) menciptakan sebuah aplikasi yang bernama Aplikasi Sistem Keuangan Desa (Siskeudes). ${ }^{3}$ Siskeudes diciptakan untuk mempermudah pemerintah desa dalam melakukan pengelolaan keuangan desa. Aplikasi tersebut di distribusikan ke seluruh pemerintah desa di Indonesia secara gratis melalui Pemerintah Kabupaten/Kota. ${ }^{4}$ Angaran Pendapatan dan Belanja Daerah (APBD) Provinsi/Kabupaten / Kota. ${ }^{5}$

Berdasarkan pengamatan dan hasil wawancara sementara dengan kepala desa Dataran Kempas Kecamatan Tebing Tinggi Kabupaten Tanjung Jabung Barat pelaksanaan aplikasi keuangan ini belum mempengaruhi pada pelaksanaan pemerintahan desa, baik dari segi pemerintahan maupun dari segi administrasi keuangan.. Hal ini dikarenakan masih terkendala dengan kualitas sumber daya manusia, sehingga dalam penyelenggaran pengelolaan administrasi keuangan

\footnotetext{
${ }^{1}$ Widhi Novianto dkk., “Telaahan Isu-Isu Strategis Desentralisasi dan Otonomi Daerah”, Jakarta, 2015, hlm. 22. Pusat Kajian Desentralisasi dan Otonomi Daerah LAN RI,

${ }^{2}$ BPKP, "Pengawalan Keuangan Desa Dengan Aplikasi Siskeudes",

${ }^{4}$ KOMINFO, “Aplikasi Siskeudes Untuk Transparansi Keuangan Desa 2018

${ }^{5}$ DwiNovianto, “Tepat Guna Pengelolaan Keuangan Desa”, CV Derwati Press, Kalimantan Barat, 2019, hlm. 6 .
} 
masih menggunakan cara manual.. Artinya dapat dikatakan bahwa hasil pengamatan ini tidak sesuai dengan maksud dan tujuan dari program atau aplikasi keuangan yang menjadi tujuan utama dalam administrasi anggaran dalam pengelolaan keuangan desa. ${ }^{6}$

\section{Rumusan Masalah}

Berdasarkan uraian di atas, maka dapat dirumuskan permasalahan yang akan menjadi kajian utama dalam penelitian yang akan dilakukan. Adapun rumusan permasalahan tersebut adalah sebagai berikut: Apa Urgensi aplikasi sistem keuangan desa (siskeudes) dalam pengelolaan keuangan desa di desa Dataran Kempas Kecamatan Tebing Tinggi Kabupaten Tanjung Jabung Barat dan Kendala apa yang dihadapi Kepala Desa dalam pelaksanaan aplikasi sistem keuangan desa.

\section{TINJAUAN PUSTAKA}

Otonomi Desa merupakan otonomi asli, bulat, dan utuh serta bukan merupakan pemberian dari Pemerintah. Sebaliknya pemerintah berkewajiban menghormati otonomi asli yang dimiliki oleh desa tersebut. Sebagai kesatuan masyarakat hukum yang mempunyai susunan asli berdasarkan hak istimewa, desa dapat melakukan perbuatan hukum publik maupun hukum perdata, memiliki kekayaan, harta benda serta dapat dituntut dan menuntut dimuka pengadilan. Pemerintah desa merupakan simbol formal dari keseluruhan masyarakat desa yang mengatur pelaksanaan kegiatan-kegiatan dan urusan pemerintahan oleh di desa dan badan permusyawaratan yang dipilih oleh masyarakat dan untuk kepentingan masyarakat.

Menurut Widjaja (2003:166) Otonomi Desa merupakan hak, wewenang dan kewajiban untuk mengatur dan mengurus sendiri urusan pemerintahan dan kepentingan masyarakat berdasarkan hak asal-usul dan nilai-nilai sosial budaya yang ada pada masyarakat untuk tumbuh dan berkembangan desa tersebut. Urusan pemerintahan berdasarkan asal-usul desa, urusan yang menjadi wewenang pemerintahan Kabupaten atau Kota di serahkan pengaturannya kepada desa. Namun dalam pelaksanaan hak, kewenangan dan kebebasan dalam penyelenggaraan otonomi desa harus tetab menjunjung nilai-nilai tanggung jawab terhadap Negara Kestuan Republik Indonesia dengan menekankan bahwa Desa adalah bagian yang tidak terpisahkan dari Bangsa dan Negara Indonesia.

Undang-Undang Nomor 6 Tahun 2014 Tentang Desa menyatakan bahwa Keuangan Desa adalah semua hak dan kewajiban desa yang dapat dinilai dengan uang serta segala sesuatu berupa uang dan barang yang berhubungan dengan pelaksanaan hak dan kewajiban desa. Hak dan kewajiban sebagaimana dimaksud pada ayat (1) menimbulakan pendapatan, belanja, pembiayaan, dan pengelolaan

${ }^{6}$ Lihat Muksin Hi. Abdullah dan Abjan SamadJournal on InformationSystem, Volume 4, Nomor 1, 2019. 
keuangan desa. Pendapatan Desa bersumber dari: (a) Pendapatan asli desa terdiri atas hasil usaha, hasil aset, swadaya dan partisipasi, gotongroyong, dan lain-lain pendapatan asli desa; (b) Alokasi anggaran pendapatan dan belanja Negara; (c) Bagian dari hasil daerah dan retribusi daerah Kabupaten/Kota; (d) Alokasi dana desa yang merupakan bagian dari dana perimbangan yang diterima Kabupaten/ Kota; (e) Hibah dan sumbangan yang tidak mengikat dari pihak ke tiga; dan (f) Lain-lain pendapatan desa yang sah.

Sebagai pelaksana dari Undang-Undang di atas, Permendagri No 113 Tahun 2014, Pengelolaan Keuangan Desa menyatakan bahwa pengelolaan keuangan desa merupakan keseluruhan kegiatan yang meliputi Perencanaan, Pelaksanaan, Penatausahaan, Pelaporan, dan Pertanggungjawaban, pengelolaan keuangan desa dilaksanakan dalam masa 1 (satu) Tahun anggaran, terhitung mulai tanggal 1 Januari sampai dengan 31 Desember.

Diterbitkannya Peraturan Mendagri No.37/2007 tentang pengelolaan keuangan desa memberikan landasan bagi semakin otonomnya desa secara praktik, bukan hanya sekedar normatif. Rilis aturan ini kemudian diikuti dengan Permendagri Nomor .66/2007 tentang perencanaan pembangunan desa, sehingga terdapat kesinambungan antara aturan mengenai perencanaan dengan pengelolaan keuangan desa. Beberapa pertanya kemudian muncul berkaitan dengan substansi, urgensi, dan relevansi kedua aturan tersebut yaitu apakah aparatur Desa, terutama Sekretaris Desa dan Bendahara, akan mampu_melaksanakan fungsiperencanaan, pelaksanaan, penatausahaan, dan pertanggungjawaban sesuai dengan yang diatur dalam Permendagri No.37/2007 tsb? Keterbatasan SDM dan kebiasaan yang berjalan selama ini harus dirubah dan diperbaikan sehingga kultur good village governance (3G) dapat merasuk ke dalam administrasi dan birokrasi desa (Syukri,2008).

Dalam kaitanini maka responsibilitas, transparansi dan akuntabilitas pengelolaan keuangan desa diartikan sebagai bagian dari suatu sistem pengelolaan keuangan daerah yang menyediakan informasi keuangan yang terbuka bagi masyarakat dalam rangka_Mewujudkan penyelenggaraan pemerintahan yang baik dan mempertanggungjawabkan pengelolaan sumber daya serta pelaksanaan kebijakan yang dipercayakan kepada unit organisasi pemerintah dalam rangka pencapaiannya.

Berdasarkan pada teori pengelolaan menyatakan bahwa Pengelolaan pada dasarnya dapat diartikan sebagai pengendalian dan pemanfaatan semua sumber daya yang menurut suatu perencanaan diperlukan untuk atau penyelesaian suatu tujuan kerja tertentu. Fungsi Pengelolaan merupakan Tahap-tahap dalam melakukan pengelolaan meliputi: perencanaan (planning),pengorganisasian (organisasi), pengarahan (actualing), dan pengawasan(controlling Pengelolaan keuangan desa pada dasarnya mengikuti pola pengelolaan keuangan daerah dimana Kepala Desa merupakan pemegang kekuasaan pengelolaan keuangan desa.Pendapatan, belanja dan pembiayaan desa harus ditetapkan dalam APBDes 
yang ditetapkan dalam Peraturan Desa oleh Kepala Desa bersama BPD.Pertanggungjawaban terhadap penggunaan dan pengelolaan keuangan desa ini merupakan tanggungjawab Kepala Desa untuk disampaikan kepada Bupati/Walikota pada setiap akhir tahun anggaran yang disampaikan melalui Camat, Badan Permusyawaratan Desa pada setiap akhir tahun anggaran, dan masyarakat dalam musyawarah desa.

Secara teori dapat dikemukakan pendapat Kuntjoro Purbopranoto ${ }^{7}$, asas-asas umum tentang pemerintahan yang baik (The General Principle of Good Administration) itu dapat dikatagorikan ke dalam 13 (tiga belas) asas yaitu: (1) Asas kepastian hukum (Principle of legal security) (2) Asas keseimbangan (principle of proportionality) (3) Asas Motivasi untuk setiap keputusan (Principle of motivation) (4) Asas kesamaan dalam mengambil keputusan (pruinciple of quality) (5) Asas bertindak cermat (principle of carefullness) (6) Asas jangan campur adukan kewenangan (principle of non misuse of competence) (7) Asas keadilan yang layak (principle of fair play) (8) Asas keadilan dan kewajaran (principle of reasonableness or prohibition of cabitrariness). (9) Asas menanggapi penghargaan yang wajar (principle of meeting raised expectation) (10) Asas meniadakan akibat-akibat suatu keputusan yang batal (principle of doing the consequences of an annualleed decision) (11) Asas perlindungan atau pandangan hidup/cara hidup pribadi (principle of protecting the personal way of life) (12) Asas kebijaksanaan (principle of police). (13) Asas penyelenggaraan Kepentingan Umum (principle of public service).

\section{METODE PENELITIAN}

Penelitian ini merupakan penelitian yang bersifat deskriptif, yaitu penelitian ini memberikan gambaran tentang Urgensi tentang perencanaan, pelaksanaan, penatausahaan, pelaporan dan pertanggungjawaban keuangan Desa. dalam pengelolaan keuangan desa dan Kendala apa saja yang dihadapi pemerintah terbawah (kepala desa beserta aparatnya dan Badan Perwakilan Desa) dalam penerapan aplikasi sistem keuangan desa dengan menggunakan cara yang dilakukan untuk mendapatkan data secara yuridi sempiris, yaitu melihat bagaimana pelaksanaan program yang sudah diatur dengan perundang-undangan dapat dilaksanakan di lapangan. (Apakah sudah sesuai antara aturan dan fakta dilapangan Dengan sumber data skunder dan data lapangan serta bahan hukum primer dan bahan hukum sekunder sebagai data penunjang. Data dikumpulkan dengan wawancara dan studi dokumen. Data dianalisi secara kualitatif, yang akan dipaparkan dalam bentuk uraian atau pernyataan. Kemudian dari analisisini akan ditarik suatu kesimpulan dengan mengguna kan metode induktif.

${ }^{7}$ Ibid. 


\section{HASIL DAN PEMBAHASAN}

\section{Urgensi aplikasi sistem keuangan desa (siskeudes) dalam pengelolaan keuangan desa di desa Dataran Kempas Kecamatan Tebing Tinggi Kabupaten Tanjung Jabung Barat}

Pengelolaan keuangan desa diatur dalam Peraturan Menteri Dalam Negeri Nomor 37 Tahun 2007 tentang Pedoman Pengelolaan Keuangan Desa. Pasal 1 angka 1 Peraturan Menteri Dalam Negeri Nomor 37 Tahun 2007 menyatakan bahwa: Pengelolaan Keuangan Desa adalah keseluruhan kegiatan yang meliputi perencanaan, penganggaran, penatausahaan, pelaporan, pertanggung-jawaban dan pengawasan keuangan desa. Selanjutnya Pasal 1 Angka 7 Peraturan Menteri Dalam Negeri Nomor 37 Tahun 2007 menyatakan bahwa Pemegang Kekuasaan Pengelolaan Keuangan Desa adalah Kepala Desa yang karena jabatannya mempunyai kewenangan menyelenggarakan keseluruhan pengelolaan keuangan desa. Sebagai pemegang kekuasaan pengelolaan keuangan desa pemerintah pemerintah desa dalam hal ini Kepala Desa diberi kewenangan untuk menetapkan kebijakan dalam pengeloaan keuangan desa sebagaimana yang dinyatakan dalam: Pasal 3 (1) menyatakan : Kepala Desa sebagai Kepala Pemerintah Desa adalah Pemegang Kekuasaan Pengelolaan Keuangan Desa dan mewakili Pemerintah Desa dalam kepemilikan kekayaan desa yang dipisahkan; Pasal 3 ayat (2) menyatakan : Kepala Desa sebagaimana dimaksud pada ayat (1) diatas, mempunyai kewenangan: a. menetapkan kebijakan tentang pelaksanaan APBDesa ; b. menetapkan kebijakan tentang pengelolaan barang desa c. menetapkan bendahara desa; d. menetapkan petugas yang melakukan pemungutan penerimaan desa; dan menetapkan petugas yang melakukan pengelolaan barang milik desa.

Sesuai dengan permasalahan yang dialami oleh Aparatur Pemerintah Desa Dataran Kempas Kecamatan Tebing Tinggi Kabupaten Tanjung Jabung Barat adalah: minimnya pengetahuan administrasi di tingkat Desa, padahal hal ini sangat penting bagi Pemerintah Desa (Kepala Desa) dan aparaturnya dalam memahami peran strategisnya sebagai hak pengguna anggaran dalam pengelolaan keuangan Desa serta pembuatan pelaporan sesuai aturan undang-undang yang berlaku dalam rangka mewujudkan Good Village Governance (Tata Kelola Pemerintahan Desa yang baik) dan Clean Government.

Melalui pelatihan dan pendampingan ini diharapkan para Aparatur Pemerintah Desa Dataran Kempas Kecamatan Tebing Tinggi Kabupaten Tanjung Jabung Barat dapat membuat:

1. penatausahaan administrasi keuangan Desa berupa pencatatan pada buku kas umum (BKU) dan buku-buku pembantunya,

2. penyusunan kelengkapan bukti pembayaran (pengeluaran) yang akan dijadikan sebagai Surat Pertanggung Jawaban (SPJ) sehingga nantinya dapat meminimalisir resiko Fraud 
seperti:

1) Program dan Kegiatan pada RPJMDes, RKPDes, dan APB Des tidak sesuai aspirasi/kebutuhan masyarakat desa;

2) Kegagalan menyelenggarakan Siklus Pengelolaan Keuangan Desa yang sehat.

3) Kegagalan atau keterlambatan penyusunan Laporan Penyelenggaraan Pemerintah Desa, termasuk Laporan Pertanggungjawaban Realisasi Pelaksanaan APBDes.

4) Pengelolaan Aset Desa yang tidak efisien dan efektif.

5) Penggunaan Kas Desa secara tidak sah (Theft of Cash on Hand). (6) Mark up dan atau Kick Back pada Pengadaan Barang/Jasa.

6) Penggunaan Aset Desa untuk kepentingan pribadi Aparat Desa secara tidak Sah (misuse atau larceny)

Berdasarkan hasil penelitian di lapanagan maka sebagian besar aparatur pengelola keuangan desa belum memiliki kualitas Sumber daya Manusia yang memadai dalam pengelolaan keuangan. Sedangkan secara teoritis, pembukuan merupakan proses pencatatan yang dilakukan secara teratur untuk mengumpulkan data dan informasi keuangan suatu perusahaan atau organisasi atau lembaga. Pencatatan itu meliputi harta, kewajiban, modal, penghasilan dan biaya, serta jumlah harga perolehan dan penyerahan barang atau jasa, yang ditutup dengan menyusun laporan keuangan berupa neraca, dan laporan laba rugi untuk periode tahun fiskal tersebut. Pembukuan dapat digunakan sebagai alat kontrol keuangan usaha. Kita dapat mengetahui biaya-biaya mana yang tidak perlu, biaya mana yang merupakan pemborosan (inefisiensi). Sehingga biaya tersebut dipotong dan akan mengefisienkan usaha dengan lebih baik. Tanpa adanya pembukuan, hal tersebut tidak akan mungkin bisa dilakukan, karena secara nyata angka itu tidak pernah tercatat

Kendala yang dihadapi Kepala Desa Dataran Kempas Kecamatan Tebing Tinggi Kabupaten Yanjung Jabung Barat dalam pelaksanaan aplikasi sistem keuangan desa.

Berdasarkan hasil penelitian, adapun kendala yang dihadapi oleh aparatur desa dalam dalam pelaksanaan aplikasi sistem keuangan desa. di Desa Dataran Kempas Kecamatan Tebing Tinggi Kabupaten Tanjung Jabung Barat adalah :

1. Kurangnya Sumber Daya manusia yang ada dalam Pengelolaan Keuangan Desa, dimana rata-rata memiliki pemahaman yang kurang mengenai penyusunan laporan keuangan dan kurangnya pemahaman mengenai aturanaturan yang ada,

2. Kurangnya ketrampilan dan ilmu pengetahuan aparatur desa tentang sistem aplikasi keuangan desa. 
3. kurangnya pemahaman pengelola keuangan desa mengenai cara penyusunan Rancangan Anggaran Biaya (RAB).

Setelah diberikan pelatihan dan pendampingan para aparatur pemerintah desa Dataran Kempas Kecamatan Tebing Tinggi Kabupaten Yanjung Jabung Barat mengakui mereka memiliki kemampuan dan keterampilan yang memadai dalam membuat pertanggungjawaban yang digunakan untuk menghitung aliran masuk dan keluarnya dana dengan memakai aplikasi walaupun belum maksimal. Artinya hanya sebagian yang dapat direalisasikan dengan memakai aplikasi.

\section{KESIMPULAN DAN SARAN}

\section{Kesimpulan}

Pelaksanaan aplikasi sistem keuangan desa di Pemerintah Desa Dataran Kempas Kecamatan Tebing Tinggi Kabupaten Tanjung Jabung Barat yang menjadi objek penelitian atau telah mulai melakukan pengelolaan keuanganan desa dengan sistem aplikasi walaupun belum maksimal. Dan masih menimbulkan banyak kendala.

\section{Saran}

Uuntuk mengoptimalkan pelaksanaan aplikasi sistem keuangan desa dalam penyelengaraan atau pengelolaan keuangan desa Dataran Kempas, pemerintah desa harus mampu mencipkan sumber daya manusia yang paham untuk mengoperasikannya dan mengadakan sarana prasarana yang lenekap sesuai kebutuhan sistim aplikasi tersebut.

\section{DAFTAR PUSTAKA}

\section{BUKU}

Abdul Rasyid Thalib. 2013. Metode Penulisan Karya Ilmiah Ilmu Hukum. Transformasi Penelitian Ilmu Sosial ke Ilmu Penelitian Hukum Normatif dan Ilmu Penelitian Empiris. Lembaga Pengkajian dan Pembaharuan Hukum dan Kebijakan Publik, Palu.

Abdulkadir Muhamad, 2001. Etika Profesi Hukum, Citra Aditya Bakti, Bandung.

Ari Dwipayana, Adrian Suntoro eko, 2003. Membangun Good Governance di Desa, Institute of Research and Empowerment, Yogyakarta: Ire Press.

Bachrul Amiq, 2010, Aspek Hukum Pengelolaan Keuangan Daerah, LaksBang Preesindo, Yokyakarta

Aswar Annas. 2017. "Interaksi Pengambilan Keputusan dan Evaluasi Kebijakan". Sulawesi: Celebes Media Perkasa. 
Fitrah, Muh dan Luthfiyah. 2017. "Metode penelitian; Penelitian Kualitatif, Tindakan kelas \& Studi Kasus". Jawa Barat: CV Jejak.

BPKP, 2015. Petunjuk Pengeoperasian Aplikasi Sistem Tata Kelola Keuangan Desa

Gunawan, Iman. 2013. Metode Penelitian Kualitatif: Teori dan Pratilik. Jakarta:Bumi Aksara.

Hasibuan, Malayu. S.P. 2007. Manajemen Sumber Daya Manusia. Jakarta: PT Bumi Aksara.

Republik Indonesia. 2014. Undang-undang No. 6 Tahun 2014 tentang Desa.

Jehan M.Malajika, Herman Karamoy, Rudy J. Pusung, Penerapan Sistem Keuangan Desa (SISKEUDES)

KOMINFO. Aplikasi Siskeudes Untuk Transparansi Keuangan Desa 2018. https://kominfo.go.id/content/detail/15734/aplikasi-siskeudes-untuktransparansi-keuangan-desa/0/artikel gpr

\section{Peraturan Perundang-Undangan}

Peraturan Pemerintah Pengganti Undang-Undang Nomor 2 tahun 2014 Tentang Pemerintahan Daerah.

Peraturan Pemerintah Nomor 43 Tahun 2014 tentang Desa.

Peraturan Pemerintah Nomor 60 Tahun 2014 tentang Dana Desa yang Bersumber dari APBN

Peraturan Menteri Dalam Negeri Nomor 5 Tahun 2007 tentang Pedoman Penataan Lembaga Kemasyarakatan.

Peraturan Menteri Dalam Negeri Nomor 37 Tahun 2007 tentang Pengelolaan Keuangan Desa.

Peraturan Menteri Dalam Negeri Nomor 38 Tahun 2007 tentang Kerja Sama Desa 